Abstracta Iranica Abstracta Iranica

Revue bibliographique pour le domaine irano-aryen

Volume 26 | 2005

Comptes rendus des publications de 2003

\title{
«The Geographic Distribution of Muslim Jurists during the First Four Centuries AH ». Islamic Law and Society, 10, 2 (2003), p. 168-181.
}

David Durand-Guédy

\section{(2) OpenEdition}

1 Journals

Édition électronique

URL : http://journals.openedition.org/abstractairanica/2601

ISSN : 1961-960X

Éditeur :

CNRS (UMR 7528 Mondes iraniens et indiens), Éditions de l'IFRI

Édition imprimée

Date de publication : 15 mai 2005

ISSN : 0240-8910

\section{Référence électronique}

David Durand-Guédy, « «The Geographic Distribution of Muslim Jurists during the First Four Centuries AH ». Islamic Law and Society, 10, 2 (2003), p. 168-181. », Abstracta Iranica [En ligne], Volume 26| 2005, document 185, mis en ligne le 08 décembre 2005, consulté le 25 septembre 2020. URL : http:// journals.openedition.org/abstractairanica/2601

Ce document a été généré automatiquement le 25 septembre 2020.

Tous droits réservés 


\title{
«The Geographic Distribution of Muslim Jurists during the First Four Centuries $\mathrm{AH}$ ». Islamic Law and Society, 10, 2 (2003), p. 168-181.
}

\author{
David Durand-Guédy
}

Cet article présente les résultats d'une large enquête statistique menée à partir du vaste corpus des tabaqāts afin d'évaluer l'importance des différents madhabs sunnites pendant les quatre premiers siècles de l'Islam (i.e. jusqu'à la création des madrasas). L'échantillon statistique est constitué de 406 fuqahā', sélectionnés parmi un total de 7.000 entrées dans 80 dictionnaires biographiques compilés du $3^{\mathrm{e}} / 9^{\mathrm{e}}$ au $11^{\mathrm{e}} / 17^{\mathrm{e}} \mathrm{s}$. Les résultats sont présentés sous forme de tableaux commentés. Ils concernent d'une part la répartition des différents madhabs à l'échelle de l'ensemble du monde musulman, d'autre part leur répartition régionales (six grandes régions ont été définies ; l'Iran et la Transoxiane sont regroupés dans un même ensemble). Les auteurs exposent d'abord leurs résultats pour l'ensemble des quatre premiers siècles de l'Islam, puis en distinguant deux périodes (avant et après le milieu du $3^{\mathrm{e}} / 9^{\mathrm{e}} \mathrm{s}$.). Dans la dernière partie de l'article, ils proposent une analyse globale de ces résultats. Cette enquête confirme largement ce que l'on savait déjà (la domination des docteurs malikites dans tout le monde arabe, la répartition équilibrée des différents madhabs en Iraq). Les principales découvertes auxquels pensent être arrivés Bernards et Nawas concernent la faible proportion des juristes changeant d'école d'une part, l'importance du hanbalisme en Iran d'autre part (notons que l'importance du mouvement hanbalite dans l'histoire de Iran avait déjà été étudiée de façon approfondie par Pourjavady, cf. notamment ses études sur Abū Manșūr al-Ișfahānī). 
INDEX

Thèmes : 4.1. Histoire médiévale

\section{AUTEURS}

DAVID DURAND-GUÉDY

IFRI - Téhéran 